\title{
Assessment of the performance of Y2SiO5-YSZ/YSZ double-layered thermal barrier coatings
}

DOI:

10.1016/j.jeurceramsoc.2018.09.024

\section{Document Version}

Accepted author manuscript

Link to publication record in Manchester Research Explorer

\section{Citation for published version (APA):}

Hao, W., Zhang, Q., Xing, C., Guo, F., Yi, M., Zhao, X., \& Xiao, P. (2018). Assessment of the performance of Y2SiO5-YSZ/YSZ double-layered thermal barrier coatings. Journal of the European Ceramic Society. https://doi.org/10.1016/j.jeurceramsoc.2018.09.024

\section{Published in:}

Journal of the European Ceramic Society

\section{Citing this paper}

Please note that where the full-text provided on Manchester Research Explorer is the Author Accepted Manuscript or Proof version this may differ from the final Published version. If citing, it is advised that you check and use the publisher's definitive version.

\section{General rights}

Copyright and moral rights for the publications made accessible in the Research Explorer are retained by the authors and/or other copyright owners and it is a condition of accessing publications that users recognise and abide by the legal requirements associated with these rights.

\section{Takedown policy}

If you believe that this document breaches copyright please refer to the University of Manchester's Takedown Procedures [http://man.ac.uk/04Y6Bo] or contact uml.scholarlycommunications@manchester.ac.uk providing relevant details, so we can investigate your claim.

\section{OPEN ACCESS}




\section{Assessment of the performance of $\mathrm{Y}_{2} \mathrm{SiO}_{5}-\mathrm{YSZ} / \mathrm{YSZ}$ double-layered thermal}

\section{barrier coatings}

Wei Hao ${ }^{\text {a }}$, Qihui Zhang ${ }^{\text {a }}$, Chen Xing a , Fangwei Guo ${ }^{\text {a }}$, Meiyu Yi ${ }^{\text {a }}$, Xiaofeng Zhao ${ }^{\text {a,* }}$,

$$
\text { Ping Xiao }{ }^{\mathrm{a}, \mathrm{b}}
$$

${ }^{a}$ Shanghai Key Laboratory of High Temperature Materials and Precision Forming, School of Materials Science and Engineering, Shanghai Jiao Tong University, 800 Dongchuan Road, Shanghai 200240, China

${ }^{\mathrm{b}}$ School of Materials, University of Manchester, MSS Tower, Manchester M13 9PL, UK

\section{Abstract:}

$\mathrm{Y}_{2} \mathrm{SiO}_{5}$ is a promising material for the thermal barrier coatings due to its low thermal conductivity, high temperature stability and exceptional resistance for molten silicate attack. However, it suffers low fracture toughness and low coefficient of thermal expansion compared with yttria-stabilized zirconia (YSZ). In this study, a composite coating approach, i.e., incorporating $\mathrm{YSZ}$ into $\mathrm{Y}_{2} \mathrm{SiO}_{5}$ coating, was employed to overcome those limitations. The double-layered $\mathrm{Y}_{2} \mathrm{SiO}_{5}-\mathrm{YSZ} / \mathrm{YSZ}$ coatings were fabricated using atomospheric plasma spraying and tested under thermal cycling at $1150{ }^{\circ} \mathrm{C}$. The phase compositions, microstructure, mechanical properties and the failure behavior were evaluated. It was found that the amorphous phase during spraying would crystallize at high temperature accompanied by volume shrinkage,

${ }^{*}$ Corresponding author: Tel./fax: +86 2154742561

E-mail address: xiaofengzhao@sjtu.edu.cn (Xiaofeng Zhao). 
leading to cracks and spallation in the coating. With YSZ addition, the composite coatings exhibited a much longer lifetime than the single phase $\mathrm{Y}_{2} \mathrm{SiO}_{5}$ coating due to a lower volume shrinkage and enhanced toughness.

Keywords: Yttrium monosilicate; Thermal barrier coatings; Yttria-stabilized zirconia;

Lifetime; Volume shrinkage

\section{Introduction}

Yttria-stabilized zirconia (7-8 wt. \%, YSZ) is the state of art material for the thermal barrier coatings (TBCs) application due to its low thermal conductivity and exceptional mechanical properties [1-4]. As the engine temperature increases, the YSZ encounters the following issues: (i) tetragonal to monoclinic phase transformation $(t-m)$ occurs at high temperature (e.g., $>1200{ }^{\circ} \mathrm{C}$ ) and lead to catastrophic failure of TBCs [5-6]; (ii) molten silicate attack becomes increasingly important which could degrade the strain tolerance of the coating and subsequently cause coating spallation [7]. To further increase the operating temperatures, new ceramic materials with low thermal conductivity, higher phase stability and resistance to molten silicate have attracted attention in recent years [4], such as rare-earth zirconate $\left(\mathrm{Ln}_{2} \mathrm{Zr}_{2} \mathrm{O}_{7}\right.$-type, $\mathrm{Ln}=\mathrm{La}, \mathrm{Sm}$ and $\left.\mathrm{Gd}\right)$ and rare-earth cerate $\left(\mathrm{La}_{2} \mathrm{Ce}_{2} \mathrm{O}_{7}\right)$ [8-9]. However, the emerging low thermal conductivity materials usually exhibit a lower fracture toughness $\left(\sim 1.2 \mathrm{MPa}{ }^{1 / 2}\right)$ compared with the YSZ, which restricts their application in TBCs $[8,10]$.

It has been reported that, the yttrium monosilicate $\left(\mathrm{Y}_{2} \mathrm{SiO}_{5}\right)$ exhibited a lower thermal conductivity $(\sim 1.2 \mathrm{~W} /(\mathrm{m} \mathrm{K}))$, excellent thermal stability and good corrosion 
resistance to molten silicates [11-12], which has been one of preferable materials for the environmental barrier coatings. When doped with $\mathrm{Eu}$ or $\mathrm{Dy}, \mathrm{Y}_{2} \mathrm{SiO}_{5}$ can also be used as luminescence materials for sensing temperature at high temperature [13]. In this regard, $\mathrm{Y}_{2} \mathrm{SiO}_{5}$ might be a candidate top coat materials for the TBCs application. However, this material suffers a lower fracture toughness $\left(\sim 1.85 \mathrm{MPa} \mathrm{m}^{1 / 2}\right)$ and smaller coefficient of thermal expansion (CTE, $~ 8 \times 10^{-6} \mathrm{~K}^{-1}$ ) compared with YSZ [14]. Previous studies indicated that incorporation of secondary phase (e.g. YSZ) could improve both the toughness and the CTE. For example, Wang et al [10] incorporated YSZ into lanthanum zirconate $\left(\mathrm{La}_{2} \mathrm{Zr}_{2} \mathrm{O}_{7}\right)$, a $~ 120 \%$ improvement in the toughness was achieved. In addition, nano-sized $\mathrm{Y}_{3} \mathrm{Al}_{5} \mathrm{O}_{12}$ (YAG) was added into the $\mathrm{La}_{2} \mathrm{Zr}_{2} \mathrm{O}_{7}$ and obtained a similar improvement for the fracture toughness [15]. Therefore, it is expected that the composite approach, i.e. incorporating $\mathrm{YSZ}$ into $\mathrm{Y}_{2} \mathrm{SiO}_{5}$ matrix might be a potential approach to enhance the fracture toughness and increase the CTE for TBCs application.

The objective of this study is to evaluate the feasibility of $\mathrm{Y}_{2} \mathrm{SiO}_{5}$ as a top coat material for TBCs application. To improve the fracture toughness and the CTE, the YSZ was added to form a $\mathrm{Y}_{2} \mathrm{SiO}_{5}$-YSZ composite coating. To avoid the reaction between $\mathrm{Y}_{2} \mathrm{SiO}_{5}$ coating and the thermally grown oxide (TGO), the double layered system, i.e., a $\mathrm{Y}_{2} \mathrm{SiO}_{5}-\mathrm{YSZ}$ upper layer and a YSZ buffer layer, was also employed with aim to increase the thermal cycling lifetime. Both of the above coatings were fabricated using atmospheric plasma spray and tested at $1150{ }^{\circ} \mathrm{C}$ in air. Then, the microstructure evolution, thermal and mechanical properties of the coatings were 
evaluated. Finally, the failure mechanisms of the $\mathrm{Y}_{2} \mathrm{SiO}_{5}-\mathrm{YSZ} / \mathrm{YSZ}$ coatings were discussed.

\section{Experimental procedure}

\subsection{Specimen preparation}

The yttrium monosilicates $\left(\mathrm{Y}_{2} \mathrm{SiO}_{5}\right)$ were synthesized by solid state reaction. The initial yttria $\left(\mathrm{Y}_{2} \mathrm{O}_{3}, 99.9 \%\right)$ and silica $\left(\mathrm{SiO}_{2}, 99.9 \%\right)$ powders were calcined with 3 mol. $\% \mathrm{LiYO}_{2}$ additive at $1500{ }^{\circ} \mathrm{C}$ for $2 \mathrm{~h}$, as detailed elsewhere [16]. The as-synthesized $\mathrm{Y}_{2} \mathrm{SiO}_{5}$ and $\mathrm{Y}_{2} \mathrm{SiO}_{5}-\mathrm{YSZ}$ powders (the mass ratios are 1:1 and 1:4) was ball-milled in isopropanol for $36 \mathrm{~h}$. The particle size of the as-milled powders was $0.5-1.0 \mu \mathrm{m}$.

To obtain good flowability and proper particle size for plasma spraying, the phase inversion assisted electrostatic spraying is used to fabricate uniform $\mathrm{Y}_{2} \mathrm{SiO}_{5}$ and $\mathrm{Y}_{2} \mathrm{SiO}_{5}$-YSZ hollow microspheres, following procedure reported previously [17].

Table 1 The thermal spraying parameters for the fabrication of bond coat and top coats.

\begin{tabular}{|c|c|c|c|c|c|}
\hline & Bond coat & $\mathrm{Y}_{2} \mathrm{SiO}_{5}$ & $\begin{array}{l}\mathrm{Y}_{2} \mathrm{SiO}_{5}-\mathrm{YSZ} \\
(1: 1)\end{array}$ & $\begin{array}{l}\mathrm{Y}_{2} \mathrm{SiO}_{5}-\mathrm{YSZ} \\
(1: 4)\end{array}$ & YSZ \\
\hline Current /A & 380 & 420 & 420 & 420 & 420 \\
\hline $\mathrm{Ar} / \mathrm{H}_{2}$ flow rate $/$ slpm & $90 / 16$ & $100 / 11$ & $110 / 15$ & $110 / 18$ & $110 / 19$ \\
\hline Feed rate $/ g \min ^{-1}$ & 4.5 & 4.5 & 4.5 & 4.5 & 4.5 \\
\hline Sparying distance $/ \mathrm{mm}$ & 100 & 90 & 90 & 90 & 90 \\
\hline Substrate temperature $/{ }^{\circ} \mathrm{C}$ & $\sim 500$ & $\sim 500$ & $\sim 500$ & $\sim 500$ & $\sim 500$ \\
\hline Coating thickness / $\mu \mathrm{m}$ & $\sim 170$ & $\sim 240$ & $\sim 280 / \sim 170$ & $\sim 280 / \sim 170$ & $\sim 280$ \\
\hline
\end{tabular}


The fabrication of the double-layered top coat was to increase $\mathrm{Y}_{2} \mathrm{SiO}_{5}$ toughness and reduce the thermal mismatch between top coat and bond coat. The bond coat was deposited by APS using the NiCoCrAlY powders (Amdry 365-2, Oerlikon Metco). Then, the top coats were deposited by APS using pure $\mathrm{Y}_{2} \mathrm{SiO}_{5}, \mathrm{Y}_{2} \mathrm{SiO}_{5}$-YSZ composite powders (the mass ratios are 1:1 and 1:4, respectively) and 7YSZ powders (Metco 204B NS, Oerlikon Metco). The parameters for the fabrication of bond coat and top coats are summarized in Table 1.

\subsection{Thermal cycling test}

The TBCs specimens $\left(15 \times 15 \times 4 \mathrm{~mm}^{3}\right)$ were tested by thermal cycling, which consisted of 10 -min heat up to $1150{ }^{\circ} \mathrm{C}, 23.5$-h dwelling at $1150{ }^{\circ} \mathrm{C}$ and followed by a 20-min air cooling. The failure of the TBCs was defined as the spallation area was $>10 \%$, which was examined using optical images plus image analysis (Image J). At least 10 specimens were used for each thermal cycling condition.

\subsection{Characterization}

\subsubsection{Structure characterization}

The phase compositions of the as-prepared powders and TBCs specimens were characterized using X-ray diffraction (XRD, Ultima IV, Rigaku) with the $\mathrm{Cu} \mathrm{Ka}$ radiation (lamda $=0.15406 \mathrm{~nm}$ ). In addition, the phase evolution of the coatings were also evaluated using Raman spectroscopy, which was performed using the Raman Microprobe (LabRAM HR, Horiba Jobin Yvon, France). A laser spot (Nd: YAG, 532 $\mathrm{nm}$ ) with a diameter of about $3 \mu \mathrm{m}$ was focused on the coating surface. The microstructures and cracks length of the specimens were characterized by field 
emission scanning electron microscopy (FE-SEM, Inspect F50, FEI).

\subsubsection{Thermal analysis}

The linear thermal expansion coefficient was obtained using a high-temperature dilatometer (DIL 402 Expedis Select/Supreme, NETZSCH, Germany). The data were continuously recorded during heating at a rate of $2{ }^{\circ} \mathrm{C} / \mathrm{min}$. The specimens were cylindrical pieces with $6 \mathrm{~mm}$ in diameter and $10 \mathrm{~mm}$ in length. Differential scanning calorimeter (DSC) measurements were conducted on a free-standing coating using a thermo gravimetric analyzer (STA449F3, NETZSCH, Germany). The specimens were heated in air at a rate of $10^{\circ} \mathrm{C} \min ^{-1}$ up to $1200{ }^{\circ} \mathrm{C}$.

In addition, the volume change of the $\mathrm{Y}_{2} \mathrm{SiO}_{5}$ coating after high temperature treatment was estimated by geometric change using a micrometer. Five free-standing $\mathrm{Y}_{2} \mathrm{SiO}_{5}$ coating specimens $\left(20 \times 10 \times 0.45 \mathrm{~mm}^{3}\right)$ were heated in air at a rate of $5{ }^{\circ} \mathrm{C}$ $\min ^{-1}$ up to $1150^{\circ} \mathrm{C}$ for $2 \mathrm{~h}$.

\subsubsection{Young's modulus, hardness and fracture toughness tests}

Young's modulus and hardness of the top coats were measured using a microindenter (Anton Paar, CPX MHT, Austria) with a diamond Vickers indenter tip. The Young's modulus and hardness were measured from the polished coating surface using unloading curves, following the Oliver and Pharr method [18]. A total of 10 indentations with $60 \mu \mathrm{m}$ interval were performed with a load of $0.5 \mathrm{~N}$ and a dwelling time of $10 \mathrm{~s}$. For fracture toughness measurements, indentations were performed at a constant load $(2 \mathrm{~N})$ on the polished surface of the top coats. The lengths of the radial cracks were measured from the center of indention based on SEM images. A total of 
10 indentations were conducted on each sample. The fracture toughness $\left(K_{I C}\right)$ was evaluated according to Eq. (1) [10, 19]:

$$
K_{I C}=\chi\left(\frac{E}{H}\right)^{1 / 2} \frac{p}{c^{3 / 2}}
$$

where $P$ is the applied load, N; $\chi$ is an empirical constant, $H$ is the hardness, GPa; $E$ is the Young's modulus, GPa and $c$ represents the average crack length determined from the four radial cracks formed from indentations, $\mathrm{m}$.

\section{Results}

\subsection{Characterization of $\mathrm{Y}_{2} \mathrm{SiO}_{5}$ powders}

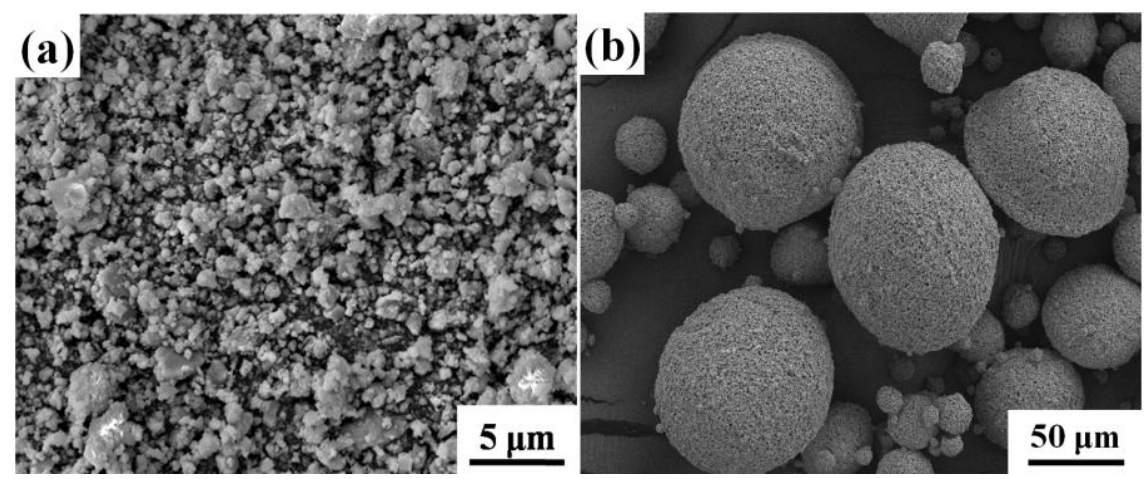

Fig. 1 SEM images of the ball-milled $\mathrm{Y}_{2} \mathrm{SiO}_{5}$ powders (a) and the as-fabricated

$\mathrm{Y}_{2} \mathrm{SiO}_{5}$ microspheres (b) by phase inversion assisted electrostatic spraying.

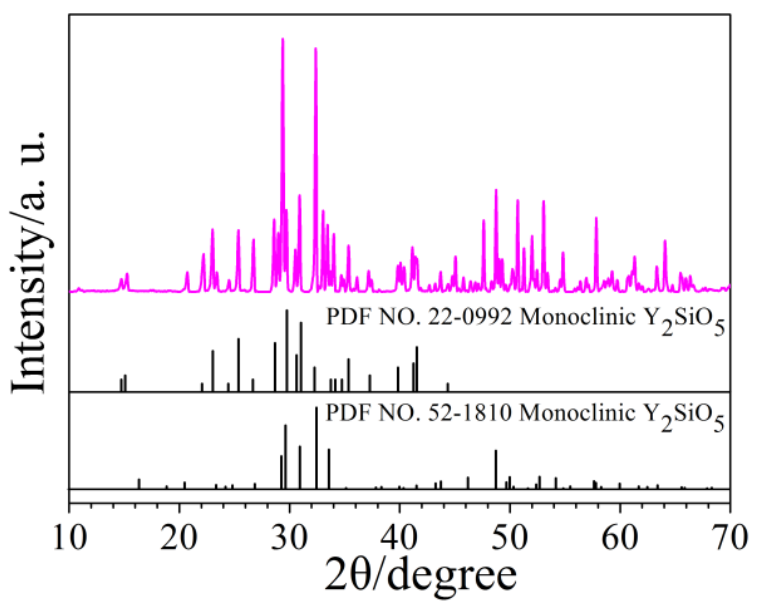

Fig. 2 XRD pattern of the ball-milled $\mathrm{Y}_{2} \mathrm{SiO}_{5}$ powders. 
The ball-milled $\mathrm{Y}_{2} \mathrm{SiO}_{5}$ powders exhibited a particle size of $\sim 2 \mu \mathrm{m}$ (Fig. 1a). To obtain good flowability and suitable particle size feeding stock for plasma spraying, $\mathrm{Y}_{2} \mathrm{SiO}_{5}$ microspheres with a particle size $(40-80 \mu \mathrm{m})$ were fabricated by phase inversion assisted electrostatic spraying (Fig. 1b) [17]. The phase composition of $\mathrm{Y}_{2} \mathrm{SiO}_{5}$ microspheres exhibited a single monoclinic phase, as shown in Fig. 2.

Thermal expansion of $\mathrm{Y}_{2} \mathrm{SiO}_{5}$ was measured from the sintered bulk using a dilatometer. The bulk specimens were prepared at $1450{ }^{\circ} \mathrm{C}$ for $2 \mathrm{~h}$ using the ball-milled $\mathrm{Y}_{2} \mathrm{SiO}_{5}$ powders. It exhibited a linear expansion $\left(\mathrm{dL} / \mathrm{L}_{0}=\left(\mathrm{L}_{-} \mathrm{L}_{0}\right) / \mathrm{L}_{0}\right)$ as the temperature ranged from $400{ }^{\circ} \mathrm{C}$ to $1200{ }^{\circ} \mathrm{C}$ (Fig. 3). The linear thermal expansion coefficient was determined using the slope of the curve of thermal expansion $v s$. temperature, which is $7.91 \pm 0.32 \times 10^{-6} \mathrm{~K}^{-1}$. This value was comparable to previous works $\left(\sim 8.4 \times 10^{-6} \mathrm{~K}^{-1}\right)[16,20]$.

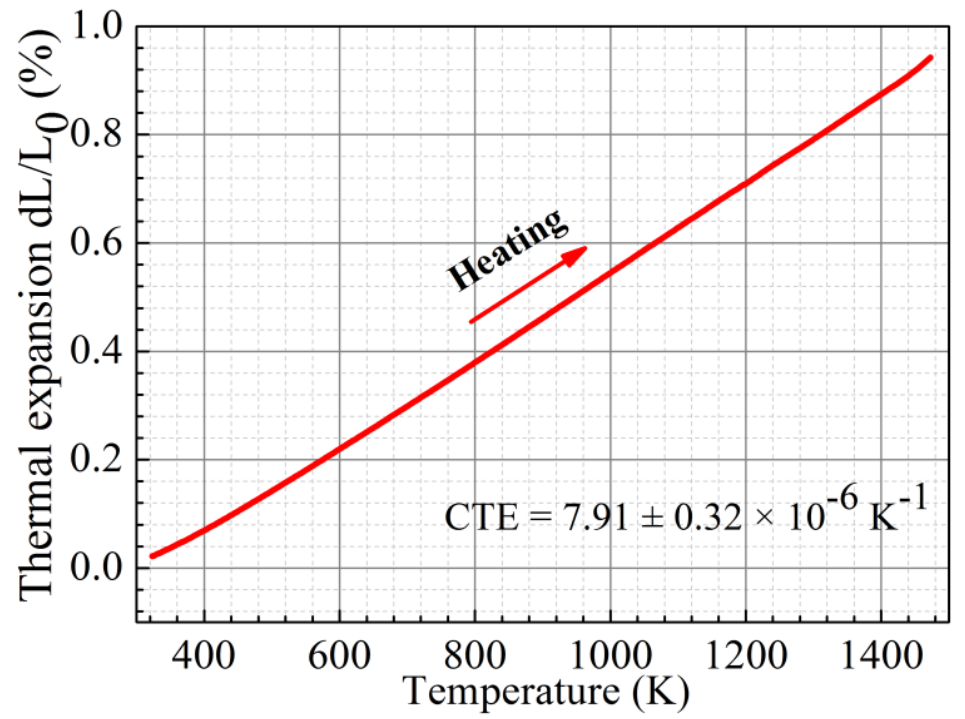

Fig. 3 Linear thermal expansion of polycrystalline $\mathrm{Y}_{2} \mathrm{SiO}_{5}$ bulk material sintered with $\mathrm{LiYO}_{2}$ additive at $1450{ }^{\circ} \mathrm{C}$ for $2 \mathrm{~h}$.

\subsection{Microstructures of $\mathrm{Y}_{2} \mathrm{SiO}_{5}$ and $\mathrm{Y}_{2} \mathrm{SiO}_{5}-\mathrm{YSZ}$ coatings}



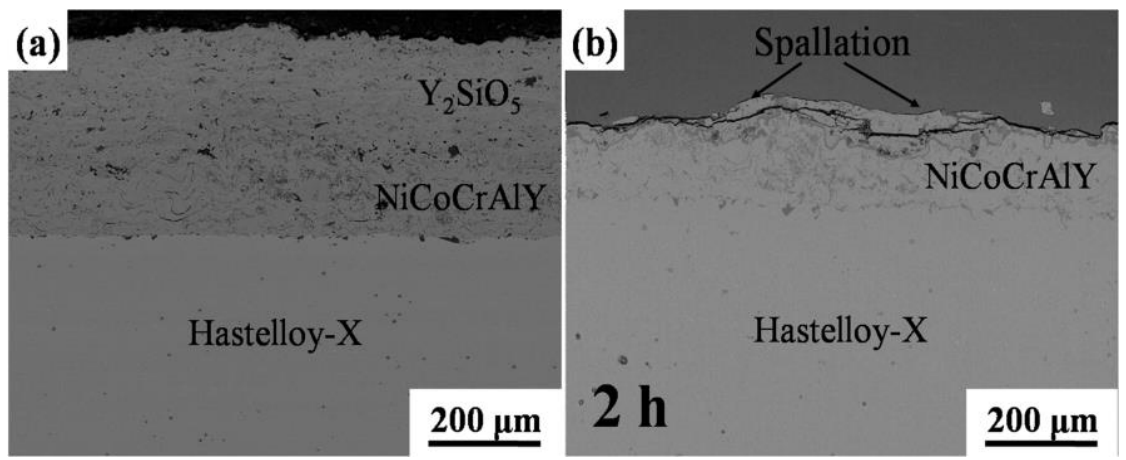

Fig. 4 Cross-sectional images of the single layer $\mathrm{Y}_{2} \mathrm{SiO}_{5}$ coatings (a) and after thermal treatment at $1150^{\circ} \mathrm{C}$ for $2 \mathrm{~h}(\mathrm{~b})$.

Fig. 4a shows cross-sectional images of the single layer $\mathrm{Y}_{2} \mathrm{SiO}_{5}$ coating in as-deposited condition. It exhibits a porous microstructure like conventional YSZ TBCs [21]. However, the top coat spalls from the bond coat completely after thermal treatment at $1150{ }^{\circ} \mathrm{C}$ for $2 \mathrm{~h}$ (Fig. 4b). Besides, the spalled coating presents fragment-like shape. This indicated that the coating has a significantly low toughness and CTE, which is responsible for the short lifetime of the coating. Thus, the composite and double-layered coatings will be fabricated to improve the lifetime of the coating.
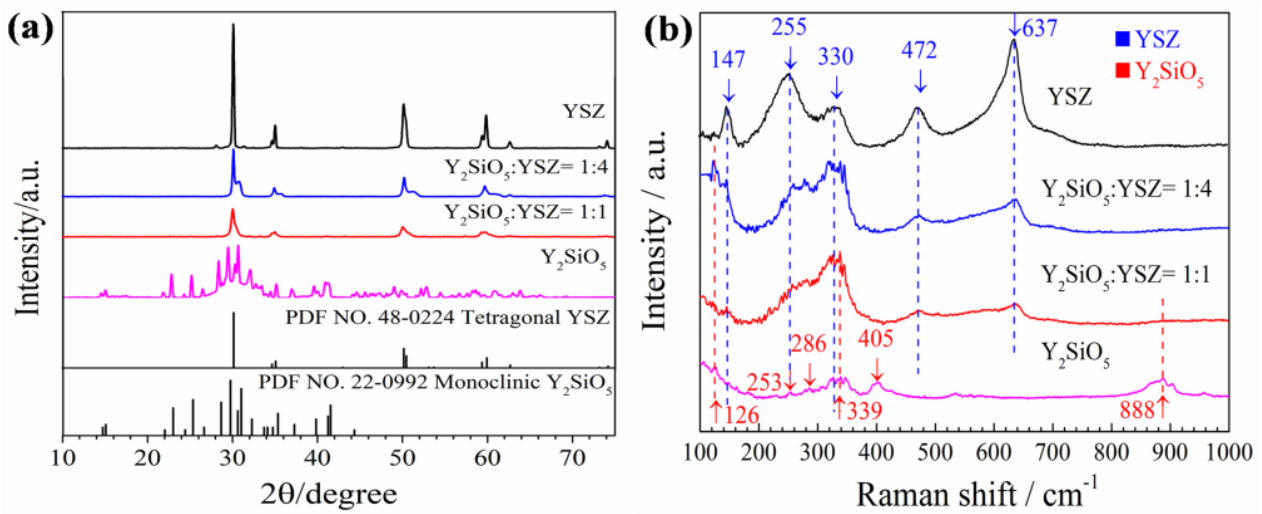

Fig. 5 Surface XRD patterns (a) and Raman spectra (b) of as-prepared $\mathrm{Y}_{2} \mathrm{SiO}_{5}-\mathrm{YSZ} / \mathrm{YSZ}$ double-layered coatings.

To improve the fracture toughness and CTE of $\mathrm{Y}_{2} \mathrm{SiO}_{5}$ top coat, a 
$\mathrm{Y}_{2} \mathrm{SiO}_{5}-\mathrm{YSZ} / \mathrm{YSZ}$ double-layered top coat was fabricated with different contents of YSZ addition into $\mathrm{Y}_{2} \mathrm{SiO}_{5}$. Fig. 5a presented XRD patterns of the $\mathrm{Y}_{2} \mathrm{SiO}_{5}-\mathrm{YSZ}$ top coats. With the composition changing from $\mathrm{Y}_{2} \mathrm{SiO}_{5}$ to $\mathrm{YSZ}$, the top coats are composed of monoclinic $\mathrm{Y}_{2} \mathrm{SiO}_{5}$, composited $\mathrm{Y}_{2} \mathrm{SiO}_{5}-\mathrm{YSZ}$ and tetragonal YSZ phases, respectively, which were also confirmed by Raman spectra (Fig. 5b). No other phases or phase transformation can be detected $[22,23]$. However, for the pure $\mathrm{Y}_{2} \mathrm{SiO}_{5}$ top coat, a small broad peak at $28^{\circ}-32^{\circ}$ was observed in the as-sprayed coatings. It indicated that the amorphous $\mathrm{Y}_{2} \mathrm{SiO}_{5}$ was generated after plasma spraying. The presence of amorphous phase in the coating is detrimental to the lifetime of TBCs since it would be crystallized at high temperature, which could introduce cracks in the top coats due to the volume shrinkage during amorphous-crystalline phase transformation.

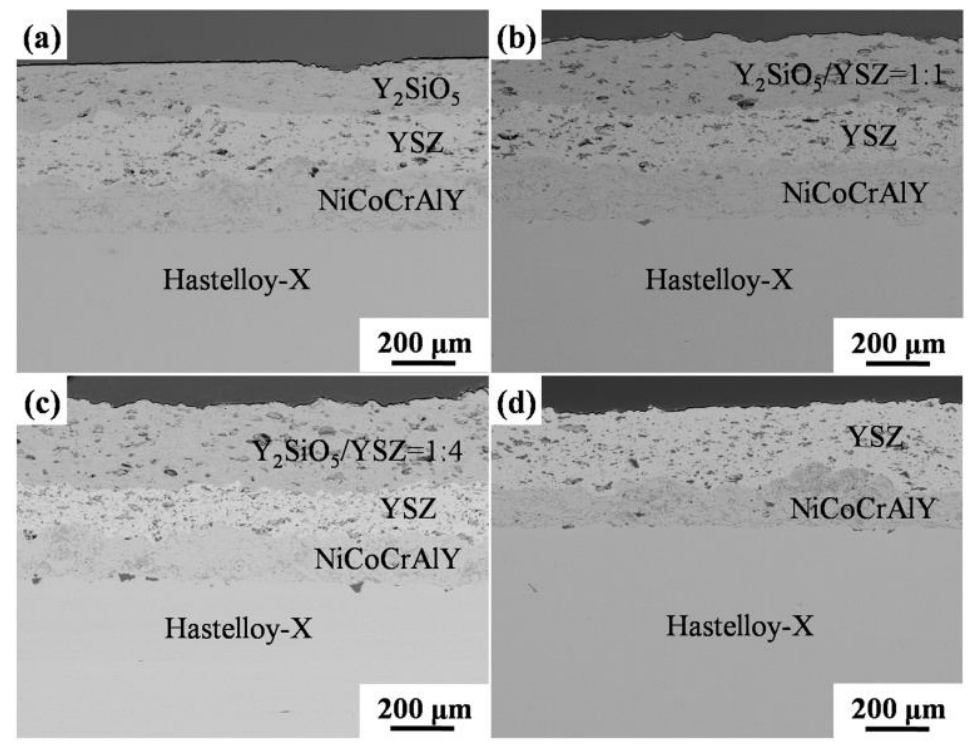

Fig. 6 Cross-sectional images of $\mathrm{Y}_{2} \mathrm{SiO}_{5}$-YSZ/YSZ double-layered coating specimens:

(a) $\mathrm{Y}_{2} \mathrm{SiO}_{5} / \mathrm{YSZ}$; (b) $\mathrm{Y}_{2} \mathrm{SiO}_{5}-\mathrm{YSZ}(1: 1) / \mathrm{YSZ}$; (c) $\mathrm{Y}_{2} \mathrm{SiO}_{5}-\mathrm{YSZ}(1: 4) / \mathrm{YSZ}$; (d) YSZ.

Fig. 6 demonstrates cross-sectional images of as-prepared $\mathrm{Y}_{2} \mathrm{SiO}_{5}-\mathrm{YSZ} / \mathrm{YSZ}$ 
double-layered coating specimens with different YSZ addition. They consist of four layers, a $\mathrm{Y}_{2} \mathrm{SiO}_{5}$-YSZ composite top layer (upper layer), a YSZ buffer layer (bottom layer), a NiCoCrAlY bond coat and a superalloy substrate. The thicknesses of the pure $\mathrm{Y}_{2} \mathrm{SiO}_{5}, \mathrm{Y}_{2} \mathrm{SiO}_{5}-\mathrm{YSZ}$ and pure $\mathrm{YSZ}$ are $\sim 240 \mu \mathrm{m}, \sim 280 \mu \mathrm{m}$ and $\sim 280 \mu \mathrm{m}$ (Fig. 6), respectively. The thickness of YSZ buffer layer is about $170 \mu \mathrm{m}$. The top layers have uniform and porous microstructure, which is attributed to partially melted YSZ or $\mathrm{Y}_{2} \mathrm{SiO}_{5}$ particles and splats structures in the APS-TBCs [24].

\subsection{Thermal cycling test of $\mathrm{Y}_{2} \mathrm{SiO}_{5}-\mathrm{YSZ} / \mathrm{YSZ}$ double-layered APS-TBCs}

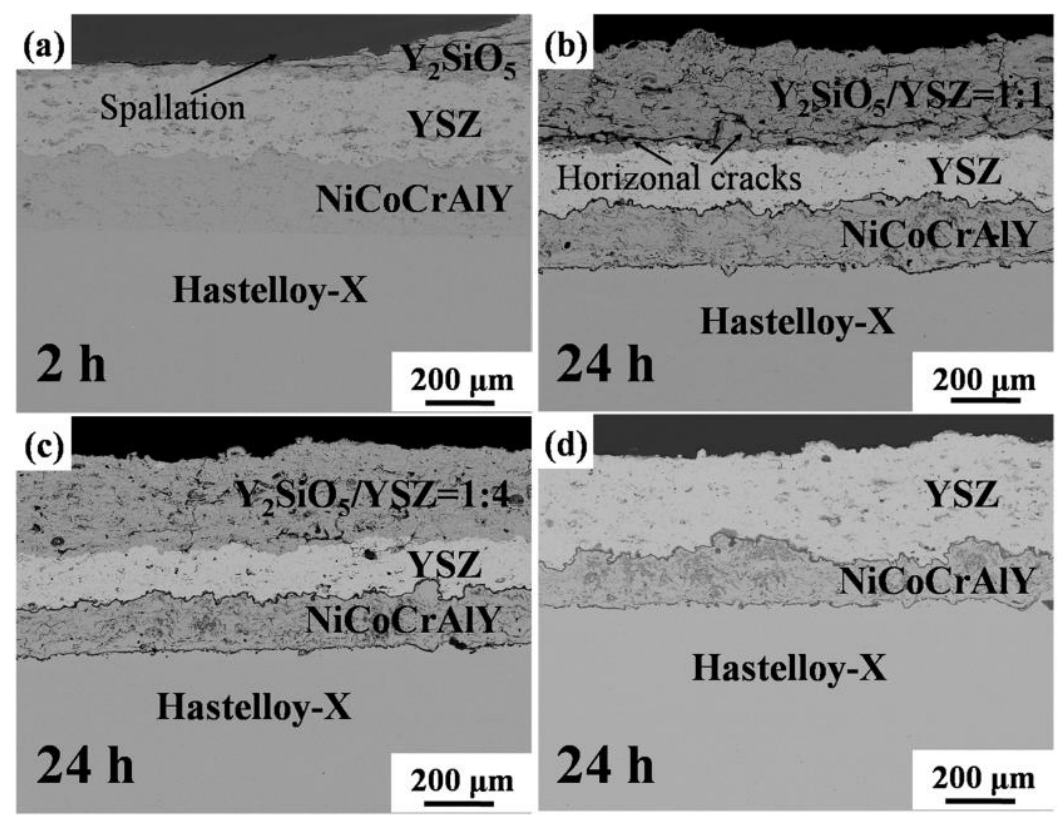

Fig. 7 Cross-sectional images of $\mathrm{Y}_{2} \mathrm{SiO}_{5}$-YSZ/YSZ double-layered coating specimens after thermal treatment at $1150{ }^{\circ} \mathrm{C}$ : (a) $\mathrm{Y}_{2} \mathrm{SiO}_{5} / \mathrm{YSZ}$ for $2 \mathrm{~h}$; (b) $\mathrm{Y}_{2} \mathrm{SiO}_{5}-\mathrm{YSZ}$ (1:1)/YSZ for $24 \mathrm{~h}$; (c) $\mathrm{Y}_{2} \mathrm{SiO}_{5}-\mathrm{YSZ}$ (1:4)/YSZ for $24 \mathrm{~h}$; (d) YSZ for $24 \mathrm{~h}$.

Fig. 7 shows cross-sectional images of the $\mathrm{Y}_{2} \mathrm{SiO}_{5}-\mathrm{YSZ} / \mathrm{YSZ}$ double-layered coating specimens after thermal cycling at $1150{ }^{\circ} \mathrm{C}$. Even with the YSZ buffer layer, the single phase $\mathrm{Y}_{2} \mathrm{SiO}_{5}$ top coat spalled completely after $2 \mathrm{~h}$ thermal treatment (Fig. 7a). The spallation can be attributed to the lower CTE of $\mathrm{Y}_{2} \mathrm{SiO}_{5}$ coating, which 
introduced a large thermal mismatch stress by the substrate. Also the low fracture toughness of $\mathrm{Y}_{2} \mathrm{SiO}_{5}$ was responsible for the short lifetime. In contrast, the $\mathrm{Y}_{2} \mathrm{SiO}_{5}$-YSZ (1:1)/YSZ coatings were still adherent after $24 \mathrm{~h}$ thermal treatment. Some vertical and horizontal cracks can be observed in Fig. 7b. The vertical cracks was generated by the tensile stress in the coating, resulted from the volume shrinkage induced by the amorphous crystallization transformation of $\mathrm{Y}_{2} \mathrm{SiO}_{5}$. The horizontal cracks along the $\mathrm{Y}_{2} \mathrm{SiO}_{5}-\mathrm{YSZ} / \mathrm{YSZ}$ interface were caused by the propagation and interaction of vertical cracks [25]. Notably, the $\mathrm{Y}_{2} \mathrm{SiO}_{5}$-YSZ (1:4)/YSZ coating specimens exhibited less vertical cracks after the same treatment (Fig. 7c) and no cracks was found in the pure YSZ TBCs (Fig. 7d).

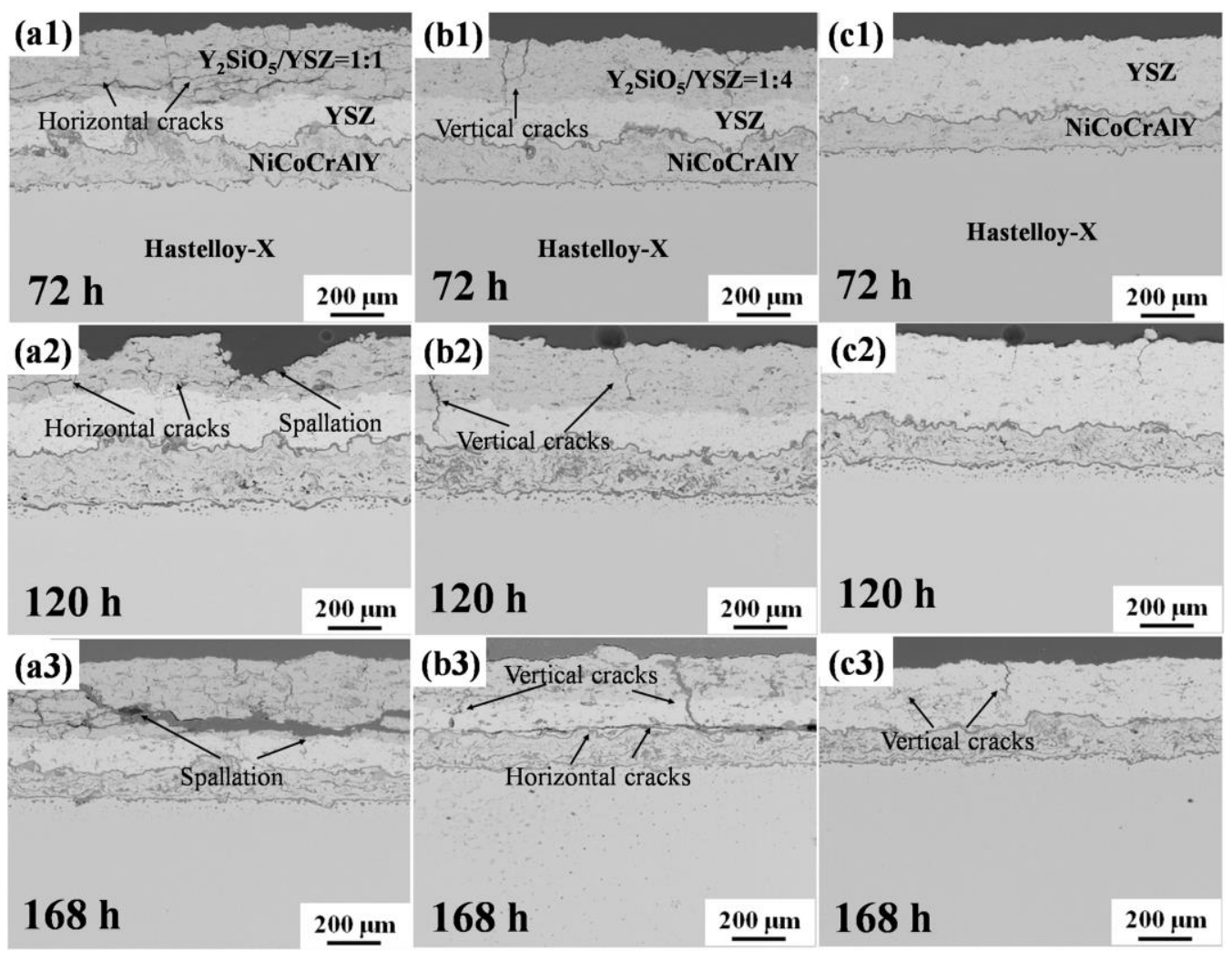

Fig. 8 Cross-sectional images of $\mathrm{Y}_{2} \mathrm{SiO}_{5}$-YSZ/YSZ double-layered coating specimens after thermal treatment at $1150{ }^{\circ} \mathrm{C}$ : (a1, a2 and a3) $\mathrm{Y}_{2} \mathrm{SiO}_{5}-\mathrm{YSZ}(1: 1) / \mathrm{YSZ} ;(\mathrm{b} 1, \mathrm{~b} 2$ 
and b3) $\mathrm{Y}_{2} \mathrm{SiO}_{5}-\mathrm{YSZ}(1: 4) / \mathrm{YSZ}$; (c1, c2 and c3) YSZ.

Fig. 8 shows cross-sectional images of $\mathrm{Y}_{2} \mathrm{SiO}_{5}-\mathrm{YSZ} / \mathrm{YSZ}$ double-layered coating specimens after thermal treatment at $1150{ }^{\circ} \mathrm{C}$ for different time. After $72 \mathrm{~h}$ thermal treatment, horizontal cracks propagated on the $\mathrm{Y}_{2} \mathrm{SiO}_{5}-\mathrm{YSZ} / \mathrm{YSZ}$ interface in the $\mathrm{Y}_{2} \mathrm{SiO}_{5}-\mathrm{YSZ}(1: 1) / \mathrm{YSZ}$ coatings, some vertical cracks bridging with horizontal cracks (Fig. 8a1). Likely, only few vertical cracks were found in the $\mathrm{Y}_{2} \mathrm{SiO}_{5}-\mathrm{YSZ}(1: 4) / \mathrm{YSZ}$ coatings (Fig. 8b1) and no apparent crack was observed for YSZ coating (Fig. 8c1). After $120 \mathrm{~h}$, partial spallation of the top layer occurred in the $\mathrm{Y}_{2} \mathrm{SiO}_{5}-\mathrm{YSZ}(1: 1) / \mathrm{YSZ}$ coatings (Fig. 8a2). For $\mathrm{Y}_{2} \mathrm{SiO}_{5}$-YSZ (1:4)/YSZ coating after $120 \mathrm{~h}$, no spallation was observed. Only some vertical cracks originated from the $\mathrm{Y}_{2} \mathrm{SiO}_{5}-\mathrm{YSZ}$ top layer into the YSZ buffer layer (Fig. 8b2). For pure YSZ TBCs, the coating was intact and few vertical cracks was presented (Fig. 8c2).

However, after $168 \mathrm{~h}$, the failure of $\mathrm{Y}_{2} \mathrm{SiO}_{5}-\mathrm{YSZ}$ (1:1)/YSZ coating specimens occurred from the $\mathrm{Y}_{2} \mathrm{SiO}_{5}$-YSZ/YSZ interface (Fig. 8a3). For the $\mathrm{Y}_{2} \mathrm{SiO}_{5}-\mathrm{YSZ}$ (1:4)/YSZ coating specimens, the horizontal cracks along the YSZ/NiCoCrAlY interface started to form by deflect of vertical cracks (Fig. 8b3), which is similar to that of YSZ top coats (Fig. 8c3) [2, 26].

Fig. 9a shows XRD patterns of $\mathrm{Y}_{2} \mathrm{SiO}_{5}$-YSZ/YSZ double-layered coatings after 2 $\mathrm{h}$ or $168 \mathrm{~h}$ thermal treatment at $1150^{\circ} \mathrm{C}$. The peak intensity of $\mathrm{Y}_{2} \mathrm{SiO}_{5}$ coating after 2 $\mathrm{h}$ thermal treatment is higher than that of as-sprayed $\mathrm{Y}_{2} \mathrm{SiO}_{5}$ coating and the broad peak disappeared due to the crystallization of amorphous $\mathrm{Y}_{2} \mathrm{SiO}_{5}$. As the content of YSZ increased, the peaks intensities of YSZ increased gradually, which is in 
agreement with Raman measurements (Fig. 9b).
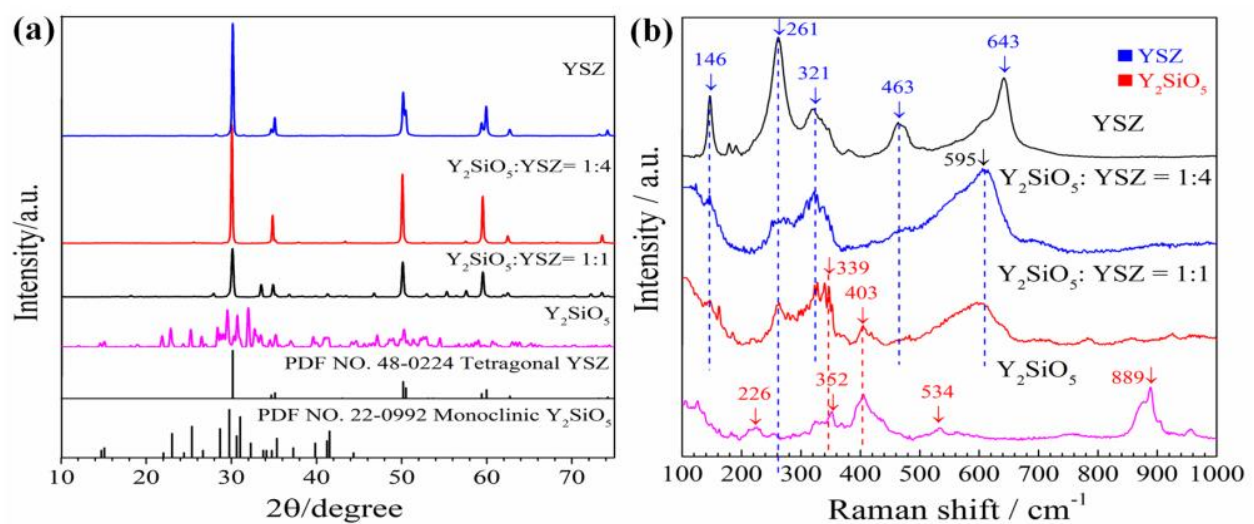

Fig. 9 XRD patterns (a) and Raman spectra (b) of $\mathrm{Y}_{2} \mathrm{SiO}_{5}-\mathrm{YSZ} / \mathrm{YSZ}$ double-layered coatings after thermal treatment at $1150{ }^{\circ} \mathrm{C}$ : $\mathrm{Y}_{2} \mathrm{SiO}_{5} / \mathrm{YSZ}$ for $2 \mathrm{~h} ; \mathrm{Y}_{2} \mathrm{SiO}_{5}-\mathrm{YSZ}$ $(1: 1) / Y S Z$ for $168 \mathrm{~h}$; $\mathrm{Y}_{2} \mathrm{SiO}_{5}$-YSZ (1:4)/YSZ for $168 \mathrm{~h}$; YSZ for $168 \mathrm{~h}$.

\subsection{Volume shrinkage derived from phase transformation}

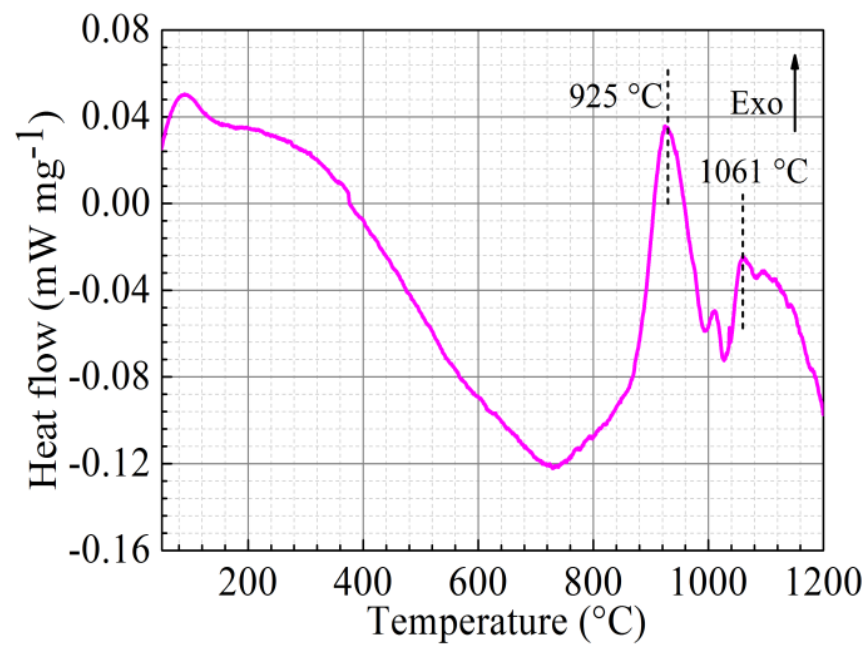

Fig. 10 DSC curve for $\mathrm{Y}_{2} \mathrm{SiO}_{5}$ free-standing coating heated to $1200{ }^{\circ} \mathrm{C}$ at a rate of $10{ }^{\circ} \mathrm{C} / \mathrm{min}$ in air.

To confirm the amorphous-crystalline transformation of $\mathrm{Y}_{2} \mathrm{SiO}_{5}$ coating specimens during thermal treatment, DSC analysis was performed on the free-standing $\mathrm{Y}_{2} \mathrm{SiO}_{5}$ coatings up to $1200{ }^{\circ} \mathrm{C}$ at a rate of $10{ }^{\circ} \mathrm{C} / \mathrm{min}$ in air (Fig. 10). The sharp exothermic peak at $925{ }^{\circ} \mathrm{C}$ corresponded to the crystallization from 
amorphous phase to $\mathrm{X} 1-\mathrm{Y}_{2} \mathrm{SiO}_{5}$ phase [16]. The exothermic peak at $1061{ }^{\circ} \mathrm{C}$ originated from $\mathrm{X} 1-\mathrm{Y}_{2} \mathrm{SiO}_{5}$ to high-temperature $\mathrm{X}_{2}-\mathrm{Y}_{2} \mathrm{SiO}_{5}$ phase transformation [27, 28]. Both of them can lead to the volume shrinkage of the top coats, resulting in a tensile stress in the $\mathrm{Y}_{2} \mathrm{SiO}_{5}$ coatings. The volume shrinkage of them before and after thermal treatment was estimated to be $(2.92 \pm 0.12) \%\left(\right.$ marked as $\left.\Delta V_{Y_{2} \mathrm{SiO}_{5}} \%\right)$.

$$
\begin{gathered}
\Delta f_{Y_{2} S_{i} O_{5}} \%=\frac{I_{(310)}^{T E}-I_{(310)}^{G C}}{I_{(310)}^{G C}} \times 100 \% \\
\Delta f \%=\left(1-\Delta W_{Y S Z} \%\right) \times \Delta f_{Y_{2} S_{i O} O_{5}} \% \\
\Delta V \%=\left(1-\Delta W_{Y S Z} \%\right) \times \Delta V_{Y_{2} S_{i O}} \%
\end{gathered}
$$

The volume shrinkage upon amorphous crystallization and phase transformation affects the nucleation and propagation of cracks [29]. Therefore, understanding phase transformation and volume shrinkage is crucial for the lifetime. Based on XRD analysis, because the peak intensity of $\mathrm{Y}_{2} \mathrm{SiO}_{5}$ phase was proportional to the content in the coating, the $\mathrm{Y}_{2} \mathrm{SiO}_{5}$ phase change fraction can be estimated according to Eq. (2) $[28,30]$, where $\Delta f_{Y_{2} S i_{5}} \%$ is the $\mathrm{Y}_{2} \mathrm{SiO}_{5}$ phase variation fraction; $I_{(310)}^{G C}$ and $I_{(310)}^{T E}$ are the (310)-peak intensity of $\mathrm{Y}_{2} \mathrm{SiO}_{5}$ (PDF NO. 22-0992) coating. The phase variation fraction and volume shrinkage in the $\mathrm{Y}_{2} \mathrm{SiO}_{5}-\mathrm{YSZ}$ top coats after thermal treatment were evaluated according to Eq. (3) and Eq. (4), respectively. Where $\Delta f \%$ is the $\mathrm{Y}_{2} \mathrm{SiO}_{5}$ phase variation fraction of $\mathrm{Y}_{2} \mathrm{SiO}_{5}$-YSZ top coats; $\Delta W_{Y S Z} \%$ is the mass ratio of $\mathrm{YSZ}$ in the $\mathrm{Y}_{2} \mathrm{SiO}_{5}-\mathrm{YSZ}$ top coats; $\Delta V \%$ is the volume shrinkage fraction caused by $\mathrm{Y}_{2} \mathrm{SiO}_{5}$ amorphous-crystalline transformation; $\Delta V_{\mathrm{Y}_{2} \mathrm{SiO}_{5}} \%$ is the volume shrinkage fraction of as-sprayed $\mathrm{Y}_{2} \mathrm{SiO}_{5}$ caused by amorphous-crystalline transformation.

Fig. 11 presented the curves for volume shrinkage and $\mathrm{Y}_{2} \mathrm{SiO}_{5}$ phase variation 
fraction in the $\mathrm{Y}_{2} \mathrm{SiO}_{5}-\mathrm{YSZ}$ top coats after thermal treatment. According to XRD analyses (Fig. 5a and Fig. 9a), there is no $t-m$ YSZ phase transformation in the top coats, the volume shrinkage derived from amorphous $\mathrm{Y}_{2} \mathrm{SiO}_{5}$ crystallization was mainly investigated in this work. The pure $\mathrm{Y}_{2} \mathrm{SiO}_{5}$ top coat exhibited a volume shrinkage of $2.92 \pm 0.12 \%$ and corresponding higher phase change fraction of $19.00 \pm 0.76 \%$ than other $\mathrm{Y}_{2} \mathrm{SiO}_{5}-\mathrm{YSZ}$ composite coating specimens. As the content of YSZ increased, the volume shrinkage decreased.

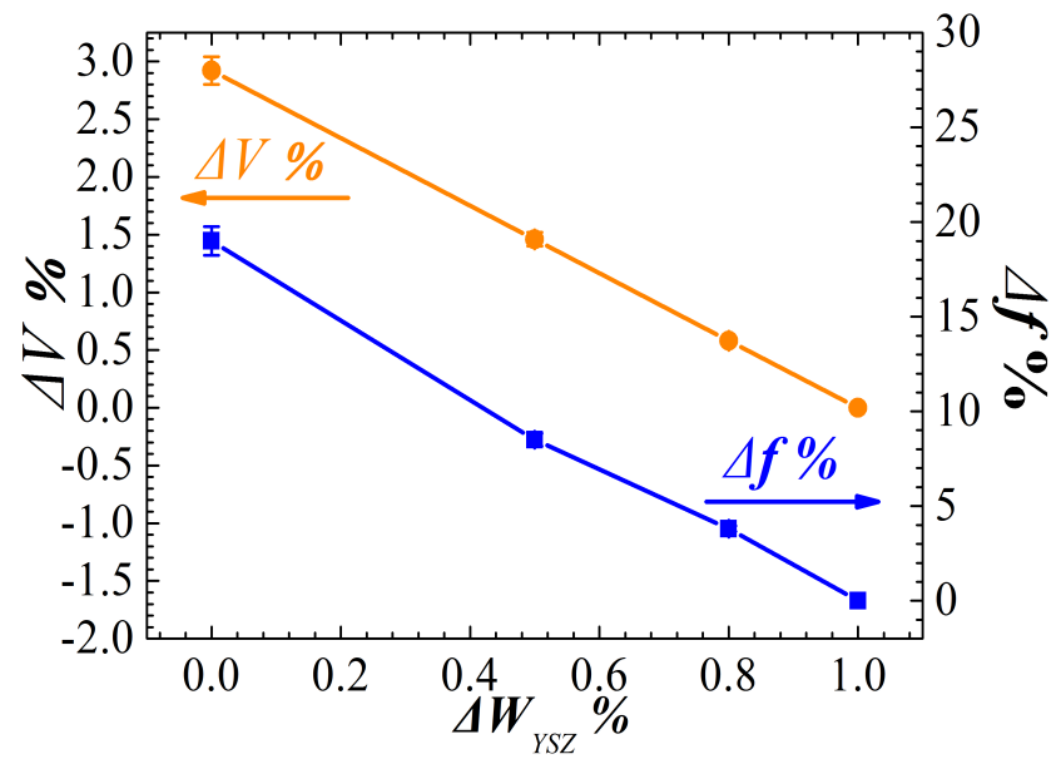

Fig. 11 Plots for the volume shrinkage and $\mathrm{Y}_{2} \mathrm{SiO}_{5}$ phase variation fraction in the $\mathrm{Y}_{2} \mathrm{SiO}_{5}-\mathrm{YSZ}$ top coats with different mass ratios of $\mathrm{YSZ}$ after thermal treatment.

\subsection{Measurement of Young's modulus and hardness}

Fig.12a presented the Young's modulus of the top coat measured using microindentation. For the as-sprayed $\mathrm{Y}_{2} \mathrm{SiO}_{5}-\mathrm{YSZ}$ coating, the Young's modulus varied from $96.96 \pm 7.03 \mathrm{GPa}$ to $104.91 \pm 7.04 \mathrm{GPa}$, close to the modulus of pure YSZ coating (102.42 \pm 3.86$)$. After $24 \mathrm{~h}$ thermal treatment, the Young' s modulus of the $\mathrm{Y}_{2} \mathrm{SiO}_{5}$-YSZ (1:1) coating specimens decreased sharply to $46.41 \pm 3.42 \mathrm{GPa}$ due to the 
occurrence of the cracks. In contrast, it increased from $124.48 \pm 21.18 \mathrm{GPa}$ to 144.38 $\pm 13.90 \mathrm{GPa}$ for $\mathrm{Y}_{2} \mathrm{SiO}_{5}$-YSZ (1:4) and YSZ coatings. Similarly, the hardness decreased to $1.03 \pm 0.27 \mathrm{GPa}$ in the $\mathrm{Y}_{2} \mathrm{SiO}_{5}-\mathrm{YSZ}$ (1:1) coating specimens, but increased from $6.85 \pm 1.39 \mathrm{GPa}$ to $7.56 \pm 1.52 \mathrm{GPa}$ in $\mathrm{Y}_{2} \mathrm{SiO}_{5}-\mathrm{YSZ}(1: 4)$ and $\mathrm{YSZ}$ coating specimens, respectively. Generally, the increase of the Young's modulus and the hardness can be attributed to the YSZ addition and the cracks in $\mathrm{Y}_{2} \mathrm{SiO}_{5}$-YSZ (1:1) coating specimens (Fig. 7b) led to a lower Young's modulus and hardness [31]. In addition, the crystallization and sintering of the coating also increase the Young's modulus and hardness [34, 35].
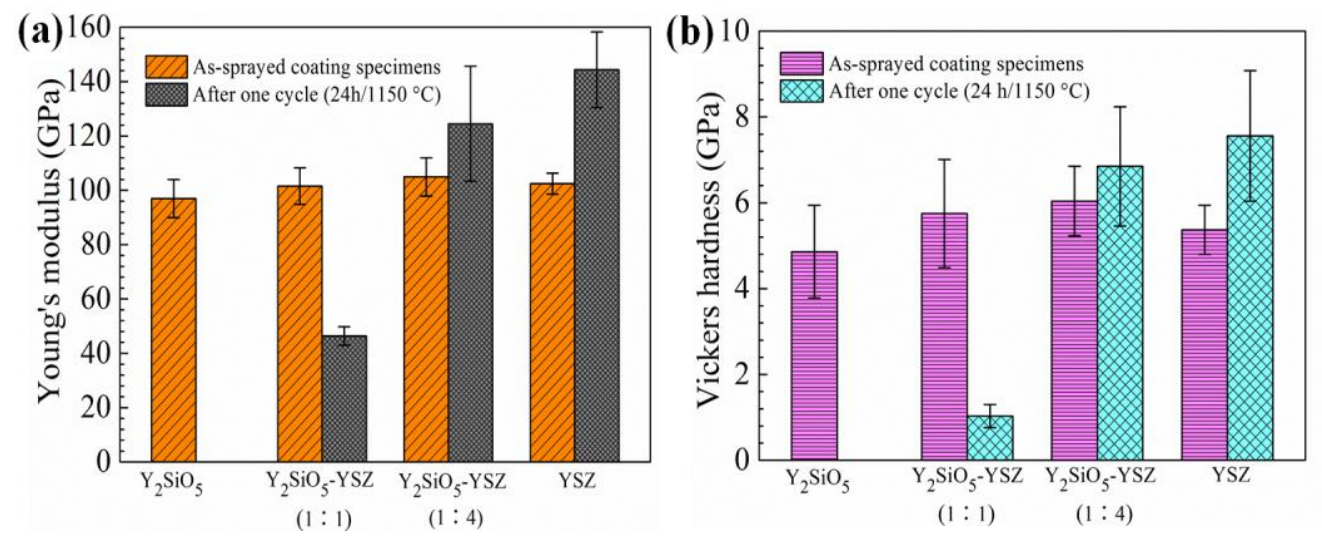

Fig. 12 Young's modulus (a) and hardness (b) of the $\mathrm{Y}_{2} \mathrm{SiO}_{5}-\mathrm{YSZ}$ top coats before and after $24 \mathrm{~h}$ thermal treatment.

\subsection{Evolution of fracture toughness after thermal treatment}

Fig. 13a shows fracture toughness of $\mathrm{Y}_{2} \mathrm{SiO}_{5}-\mathrm{YSZ}$ top coats measured using Vickers indentation. For the as-sprayed coating, the fracture toughness slightly increased from $2.22 \pm 0.18 \mathrm{MPa} \mathrm{m}^{1 / 2}$ to $2.69 \pm 0.19 \mathrm{MPa} \mathrm{m}^{1 / 2}$ as the content of $\mathrm{YSZ}$ increases. After $24 \mathrm{~h}$ thermal treatment, the fracture toughness slightly decrease in all specimens, varying from $1.90 \pm 0.22 \mathrm{MPa} \mathrm{m}^{1 / 2}$ to $2.61 \pm 0.16 \mathrm{MPa} \mathrm{m}^{1 / 2}$. This 
phenomenon was consistent with previous report $[14,32]$, which can be attributed to the sintering and the formation of the cracks. In summary, the toughness of the coating showed little improvement with YSZ addition. This indicated that the lifetime improvement by adding YSZ was mainly attributed to the increased CTE and less volume shrinkage.
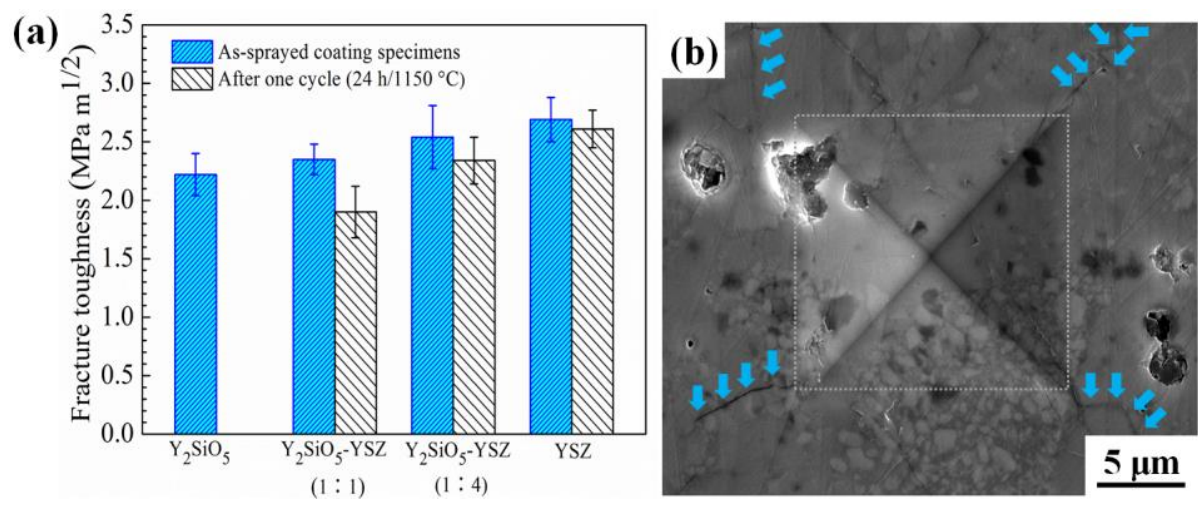

Fig. 13 Fracture toughness of as-sprayed $\mathrm{Y}_{2} \mathrm{SiO}_{5^{-}} \mathrm{YSZ}$ top coats before and after $24 \mathrm{~h}$ thermal treatment (a) and indentation morphology on polished surface of the $\mathrm{Y}_{2} \mathrm{SiO}_{5}$-YSZ top coat (b).

\section{Discussion}

Rare earth monosilicates such as $\mathrm{Y}_{2} \mathrm{SiO}_{5}$ have low thermal conductivity, high temperature stability and exceptional resistance to molten silicate attack [33]. Therefore, in this study, $\mathrm{Y}_{2} \mathrm{SiO}_{5}$ coating has been developed to fabricate as a top coating for TBCs, which can enhance the resistance to molten silicate attack of conventional YSZ TBCs. However, the single $\mathrm{Y}_{2} \mathrm{SiO}_{5}$ top coating spalled completely with $2 \mathrm{~h}$ thermal treatment. Because $\mathrm{Y}_{2} \mathrm{SiO}_{5}$ coating exhibited a lower fracture toughness $\left(\sim 1.85 \mathrm{MPa} \mathrm{m}^{1 / 2}\right)$ and smaller coefficient of thermal expansion (CTE, $\sim 8 \times 10^{-6} \mathrm{~K}^{-1}$ ) compared with YSZ [14], leading to its complete spallation with 
fragment-like shape. Here we have designed and fabricated double-layered $\mathrm{Y}_{2} \mathrm{SiO}_{5}-\mathrm{YSZ} / \mathrm{YSZ}$ to enhance the lifetime of $\mathrm{Y}_{2} \mathrm{SiO}_{5}$ coating. The double-layered coating lifetime improved remarkably from $2 \mathrm{~h}$ to $168 \mathrm{~h}$ at $1150{ }^{\circ} \mathrm{C}$ in the $\mathrm{Y}_{2} \mathrm{SiO}_{5}$-YSZ (1:4) coating specimens. These results underline the need for systematic and rational comparison of volume shrinkage, toughness and CTE in $\mathrm{Y}_{2} \mathrm{SiO}_{5}$-YSZ/YSZ specimens with adding different YSZ, which can identify the failure mechanism of them.

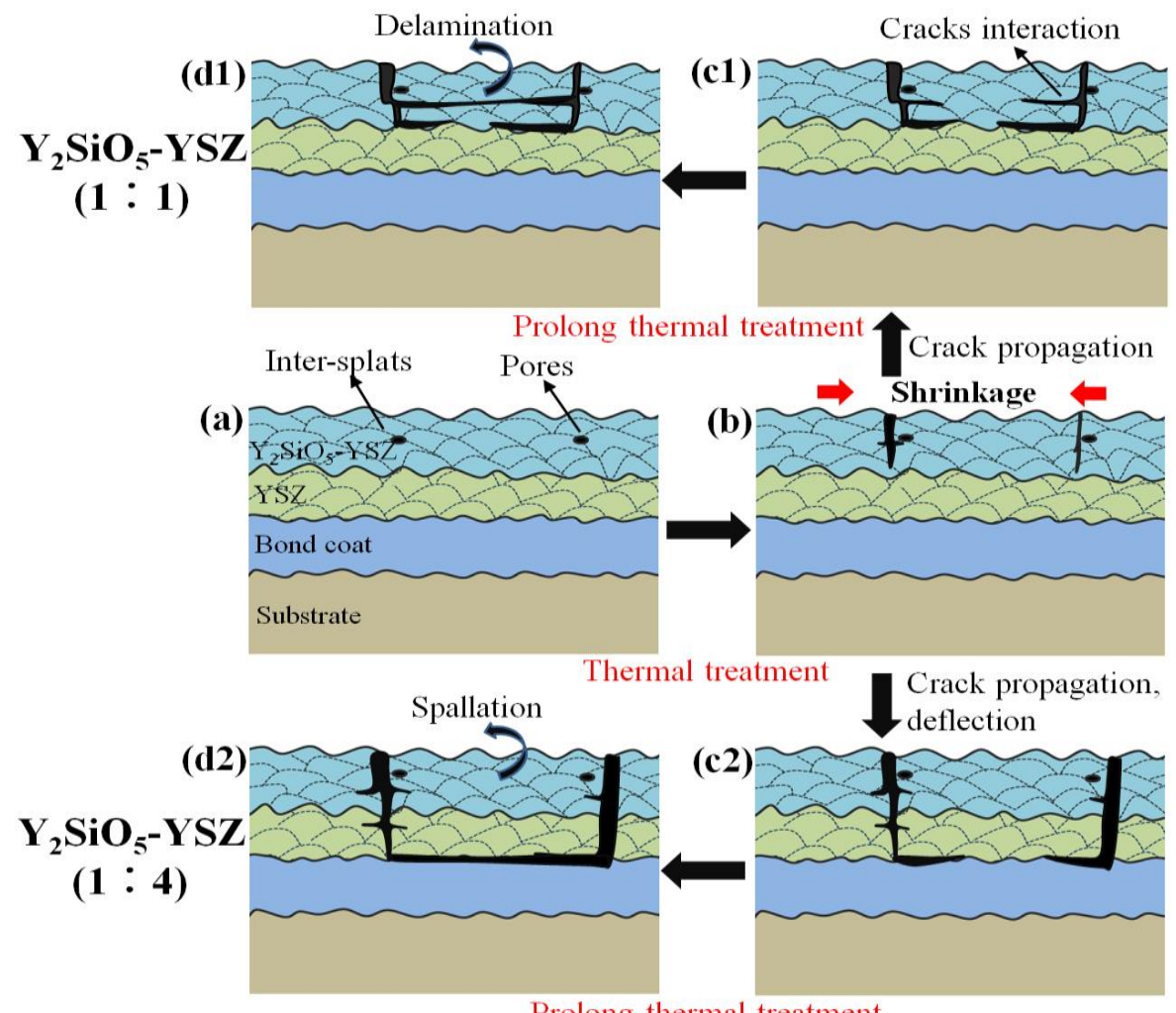

Prolong thermal treatment

Fig. 14 Schematic illustration of the proposed failure model of the $\mathrm{Y}_{2} \mathrm{SiO}_{5}-\mathrm{YSZ} / \mathrm{YSZ}$ double-layered APS TBCs.

From the XRD analyses of $\mathrm{Y}_{2} \mathrm{SiO}_{5}-\mathrm{YSZ}$ coating specimens, the broad peaks of $\mathrm{Y}_{2} \mathrm{SiO}_{5}$ changed into sharp peaks in all coating specimens after thermal treatment (Fig. 5a and Fig. 9a). It can be found that the as-sprayed $\mathrm{Y}_{2} \mathrm{SiO}_{5}$ and $\mathrm{Y}_{2} \mathrm{SiO}_{5}-\mathrm{YSZ}$ top coat 
can occur the amorphous-crystalline transformation under thermal treatment at $1150{ }^{\circ} \mathrm{C}$, which causes the volume shrinkage confirmed by DSC and volume shrinkage estimation (Fig. 10 and Fig. 11). The rare earth monosilicates always had different polymorphs which can easily occur the phase transformation accompanied by the volume change during serving [33]. It is detrimental to the lifetime of the coating specimens. So, the proposed failure mechanisms of the $\mathrm{Y}_{2} \mathrm{SiO}_{5}$-YSZ/YSZ double-layered APS TBCs after thermal treatment are illustrated in Fig. 14. The volume shrinkage in the coatings can trigger the cracking initiation and propagation [34], as shown in Fig. 14a and Fig. 14b. The vertical cracks deflection/branching resulted in horizontal cracking in the $\mathrm{Y}_{2} \mathrm{SiO}_{5}-\mathrm{YSZ} / \mathrm{YSZ}$ or $\mathrm{YSZ} / \mathrm{NiCoCrAlY}$ interface (Fig. 14c1 and Fig. 14d1) [31, 35], finally leading to the coating delamination and spallation. As the content of YSZ increased in the $\mathrm{Y}_{2} \mathrm{SiO}_{5}-\mathrm{YSZ}$ coatings, the amorphous-crystalline transformation gradually weakened with the volume shrinkage retarded. The amount of cracks reduced and the cracks exhibited from random to vertical direction, as observed in Fig. 8a1 and Fig. 8b1. Therefore, the volume shrinkage is the main factor for the failure of $\mathrm{Y}_{2} \mathrm{SiO}_{5}-\mathrm{YSZ} / \mathrm{YSZ}$ coating specimens. With adding YSZ as the bottom ceramic layer, the thermal mismatch between the $\mathrm{Y}_{2} \mathrm{SiO}_{5}-\mathrm{YSZ}_{\mathrm{SZ}}$ top coats and the bond coat was reduced, which can be beneficial for releasing their tensile stress during heating process and improving their strain tolerance [33]. The spallation from the $\mathrm{Y}_{2} \mathrm{SiO}_{5}-\mathrm{YSZ} / \mathrm{YSZ}$ interface can be restrained and the spallation model is similar to the failure behavior of conventional YSZ TBCs [35, 36] (Fig. $8 b 3$ and Fig. 8c3), as shown in Fig. 14c2 and Fig.14d2. 
From the result of fracture toughness, it is apparent that the toughness of $\mathrm{Y}_{2} \mathrm{SiO}_{5}$-YSZ top coats exhibited only a bit improvement with adding YSZ. The toughness of $\mathrm{Y}_{2} \mathrm{SiO}_{5}-\mathrm{YSZ}$ coating specimens before and after $24 \mathrm{~h}$ thermal treatment had a little decline. However, the coating lifetime presented a large variation, i.e., the $\mathrm{Y}_{2} \mathrm{SiO}_{5}$-YSZ (1:4) coating specimens could serve for $168 \mathrm{~h}$ and the pure $\mathrm{YSZ}$ coating specimens had much longer lifetime than other specimens.

\section{Conclusions}

In summary, $\mathrm{Y}_{2} \mathrm{SiO}_{5}$ and $\mathrm{Y}_{2} \mathrm{SiO}_{5}-\mathrm{YSZ} / \mathrm{YSZ}$ double-layered $\mathrm{TBC}$ were developed and fabricated due to the unique properties of $\mathrm{Y}_{2} \mathrm{SiO}_{5}$. With the incorporation of $\mathrm{YSZ}$, the lifetime of the $\mathrm{Y}_{2} \mathrm{SiO}_{5}-\mathrm{YSZ} / \mathrm{YSZ}(1: 4)$ coating specimens increased from $2 \mathrm{~h}$ to $168 \mathrm{~h}$, the improvement of corresponding thermal cycling is more than 7-fold compared with the monolithic $\mathrm{Y}_{2} \mathrm{SiO}_{5}$ and $\mathrm{Y}_{2} \mathrm{SiO}_{5} / \mathrm{YSZ}$ coating specimens after the same thermal treatment. The following conclusions can be drawn:

(1) The introduction of YSZ is an effective approach in suppressing the volume shrinkage caused by $\mathrm{Y}_{2} \mathrm{SiO}_{5}$ amorphous-crystalline transformation after thermal treatment. Additionally, the thermal mismatch between the $\mathrm{Y}_{2} \mathrm{SiO}_{5}-\mathrm{YSZ}$ top coats and the bond coat was reduced using YSZ as buffer layer, significantly enhancing the lifetime of the $\mathrm{Y}_{2} \mathrm{SiO}_{5}-\mathrm{YSZ} / \mathrm{YSZ}$ coating specimens.

(2) With adding $\mathrm{YSZ}$, the fracture toughness of $\mathrm{Y}_{2} \mathrm{SiO}_{5}-\mathrm{YSZ}$ coating specimens before and after thermal treatment had a little decline. Thus, the change of fracture toughness is not a major reason for the failure of the $\mathrm{Y}_{2} \mathrm{SiO}_{5}-\mathrm{YSZ}$ coating specimens.

(3) The failure of the $\mathrm{Y}_{2} \mathrm{SiO}_{5}$-YSZ/YSZ coating is mainly attributed to the 
$\mathrm{Y}_{2} \mathrm{SiO}_{5}$ amorphous-crystalline transformation accompanied by volume shrinkage of the $\mathrm{Y}_{2} \mathrm{SiO}_{5}-\mathrm{YSZ}$ upper layer. Consequently, the composite multilayered coating for rare-earth monosilicates is an effective way to improving the lifetime for TBCs.

\section{Acknowledgments}

This work has been supported by the Baotou Materials Research Institute of Shanghai Jiao Tong University (No. 17H500000032).

\section{References}

[1] Z.H. Zou, L.B. Jia, L.X. Yang, X. Shan, L.R. Luo, F.W. Guo, X.F. Zhao, P. Xiao, Role of internal oxidation on the failure of air plasma sprayed thermal barrier coatings with a double-layered bond coat, Surf. Coat. Technol. 319 (2017) $370-377$.

[2] W. Nowak, D. Naumenko, G. Mor, F. Mor, D.E. Mack, R. Vassen, L. Singheiser, W.J. Quadakkers, Effect of processing parameters on MCrAlY bondcoat roughness and lifetime of APS-TBC systems, Surf. Coat. Technol. 260 (2014) $82-89$.

[3] S. Guo, Y. Kagawa, Effect of thermal exposure on hardness and Young's modulus of EB-PVD yttria-partially-stabilized zirconia thermal barrier coatings, Ceram. Int. 32 (2006) 263-270.

[4] Z.G. Liu, W.H. Zhang, J.H. Ouyang, Y. Zhou, Novel double-ceramic-layer $\left(\mathrm{La}_{0.8} \mathrm{Eu}_{0.2}\right)_{2} \mathrm{Zr}_{2} \mathrm{O}_{7} / \mathrm{YSZ}$ thermal barrier coatings deposited by plasma spraying, Ceram. Int. 40 (2014) 11277-11282.

[5] U. Schulz, Phase transformation in EB-PVD yttria partially stabilized zirconia 
thermal barrier coatings during annealing, J. Am. Ceram. Soc. 83 (2000) 904-910.

[6] V. Lughiw, D.R. Clarke, Transformation of electron-beam physical vapor-deposited $8 \mathrm{wt} \%$ yttria-stabilized zirconia thermal barrier coatings, J. Am. Ceram. Soc. 88 (2005) 2552-2558.

[7] R. Naraparaju, U. Schulz, P. Mechnich, P. Döbber, F. Seidel, Degradation study of 7 wt.\% yttria stabilized zirconia (7YSZ) thermal barrier coatings on aero-engine combustion chamber parts due to infiltration by different $\mathrm{CaO}-\mathrm{MgO}-\mathrm{Al}_{2} \mathrm{O}_{3}$ $-\mathrm{SiO}_{2}$ variants, Surf. Coat. Technol. 260 (2014) 73-81.

[8] R. Vaßen, F. Traeger, D. Stöver, New thermal barrier coatings based on pyrochlore/YSZ double-layer systems, Int. J. Appl. Ceram. Technol. 1 (2004) $351-361$.

[9] L.H. Gao, H.B. Guo, S.K. Gong, H.B. Xu, Plasma-sprayed $\mathrm{La}_{2} \mathrm{Ce}_{2} \mathrm{O}_{7}$ thermal barrier coatings against calcium-magnesium-alumina-silicate penetration, J. Eur. Ceram. Soc. 34 (2014) 2553-2561.

[10] Y.F. Wang, P. Xiao, The phase stability and toughening effect of 3Y-TZP dispersed in the lanthanum zirconate ceramics, Mater. Sci. Eng. A. 604 (2014) $34-39$.

[11] Z.L. Tian, L.Y. Zheng, J.M. Wang, P. Wan, J.L. Li, J.Y. Wang, Theoretical and experimental determination of the major thermo-mechanical properties of $\mathrm{RE}_{2} \mathrm{SiO}_{5}(\mathrm{RE}=\mathrm{Tb}, \mathrm{Dy}, \mathrm{Ho}, \mathrm{Er}, \mathrm{Tm}, \mathrm{Yb}, \mathrm{Lu}$, and $\mathrm{Y})$ for environmental and thermal barrier coating applications, J. Eur. Ceram. Soc. 36 (2016) 189-202. 
[12] N.A. Nasiri, N. Patra, D. Horlait, D.D. Jayaseelan, W.E. Lee, Thermal properties of rare-earth monosilicates for $\mathrm{EBC}$ on Si-based ceramic composites, J. Am. Ceram. Soc. 99 (2016) 589-596.

[13] M.D. Chambers, P.A. Rousseve, D. R. Clarke, Luminescence thermometry for environmental barrier coating materials, Surf. Coat. Technol. 203 (2008) $461-465$.

[14] Z.Q. Sun, J.Y. Wang, M.S. Li, Y.C. Zhou, Mechanical properties and damage tolerance of $\mathrm{Y}_{2} \mathrm{SiO}_{5}$, J. Eur. Ceram. Soc. 28 (2008) 2895-2901.

[15] J.Y. Li, H. Dai, X.H. Zhong, Y.F. Zhang, X.F. Ma, J. Meng, X.Q. Cao, Effect of the addition of $\mathrm{YAG}\left(\mathrm{Y}_{3} \mathrm{Al}_{5} \mathrm{O}_{12}\right)$ nanopowder on the mechanical properties of lanthanum zirconate, Mater. Sci. Eng. A. 460 (2007) 504-508.

[16] Z.Q. Sun, Y.C. Zhou, M.S Li, Effect of $\mathrm{LiYO}_{2}$ on the synthesis and pressureless sintering of $\mathrm{Y}_{2} \mathrm{SiO}_{5}$, J. Mater. Res. 23 (2008) 732-736.

[17] Z.H. Zou, C. Xing, X. Shan. F.W. Guo, X.F. Zhao, P. Xiao, A highly strain and damage tolerant thermal barrier coating fabricated by electro-sprayed zirconia hollow spheres, J. Am. Ceram. Soc. 00 (2018) 1-12.

[18] W.C. Oliver, G.M.J. Pharr, An improved technique for determining hardness and elastic modulus using load and displacement sensing indentation experiments, J. Mater. Res. 7 (1992) 1564-1583.

[19] Y.H. Chu, H.J. Li, Y.J. Wang, L.H. Qi, Q.G. Fu, Microstructure and mechanical properties of ultrafine bamboo-shaped SiC rod-reinforced HfC ceramic coating, Surf. Coat. Technol. 235 (2013) 577-581. 
[20] Z.Q. Sun, M.S. Li, Y.C. Zhou, Recent progress on synthesis, multi-scale structure, and properties of Y-Si-O oxides, Int. Mater. Rev. 59 (2014) 357-383.

[21] K. Ma, J.G. Zhu, H.M. Xie, H.X. Wang, Effect of porous microstructure on the elastic modulus of plasma-sprayed thermal barrier coatings: experiment and numerical analysis, Surf. Coat. Technol. 235 (2013) 589-595.

[22] P. Dahl, I. Kaus, Z. Zhao, M. Johnsson, M. Nygren, K. Wiik, T. Grande, M.A. Einarsrud, Densification and properties of zirconia prepared by three different sintering techniques, Ceram. Int. 33 (2007) 1603-1610.

[23] L.X. Yang, D. Peng, C.S. Zhao, C. Xing, F.W. Guo, Z.Q. Yao, Y.Z. Liu, X.F. Zhao, P. Xiao, Evaluation of the in-depth temperature sensing performance of Eu- and Dy-doped YSZ in air plasma sprayed thermal barrier coatings, Surf. Coat. Technol. 316 (2017) 210-218.

[24] R. Ghasemi, H. Vakilifard, Plasma-sprayed nanostructured YSZ thermal barrier coatings: Thermal insulation capability and adhesion strength, Ceram. Int. 43 (2017) 8556-8563.

[25] A.A. Kulkarni, A. Goland, H. Herman, A.J. Allen, J. Ilavsky, L. Gabrielle, C.A. Johnson, J.A. Ruud, Microstructure-property correlations in industrial thermal barrier coatings, J. Am. Ceram. Soc. 87 (2004) 1294-1300.

[26] M. Gell, L. Xie, X. Ma, E.H. Jordan, N.P. Padture, Highly durable thermal barrier coatings made by the solution precursor plasma spray process, Surf. Coat. Technol. 177 (2004) 97-102.

[27] J.G. Wang, S.J. Tian, G.B. Li, F.H. Liao, X.P. Jing, Preparation and X-ray 
characterization of low-temperature phases of $\mathrm{R}_{2} \mathrm{SiO}_{5}$ ( $\mathrm{R}=$ rare earth elements), Mater. Res. Bull. 36 (2001) 1855-1861.

[28] J. Epp, X-ray diffraction (XRD) techniques for materials characterization. In: G. Huebschen, I. Altpeter, R. Tschuncky, H.G. Herrmann editors. Materials characterization using Nondestructive Evaluation (NDE) methods. Cambridge: Woodhead Publishing, (2016) 81-124.

[29] L.R. Luo, X.L. Zhang, Z.H. Zou, F.W. Guo, H. Qi, X.F. Zhao, P. Xiao, Improved the Durability of Thermal Barrier Coatings with Interface Modified by Three-Dimensional Mesh Patterns, J. Am. Ceram. Soc. 99 (2016) 3406-3410.

[30] G. Witz, V. Shklover, W. Steurer, S. Bachegowda, H.P. Bossmann, Phase evolution in yttria-stabilized zirconia thermal barrier coatings studied by rietveld refinement of X-Ray powder diffraction patterns, J. Am. Ceram. Soc. 90 (2007) 2935-2940.

[31] H.B. Guo, R. Vaßen, D. Stöver, Atmospheric plasma sprayed thick thermal barrier coatings with high segmentation crack density, Surf. Coat. Technol. 186 (2004) 353-363.

[32] W.G. Mao, J. Wan, C.Y. Dai, J. Ding, Y. Zhang, Y.C. Zhou, C. Lu. Evaluation of microhardness, fracture toughness and residual stress in a thermal barrier coating system: A modified Vickers indentation technique, Surf. Coat. Technol. 206 (2012) 4455-4461.

[33] (a) K.N. Lee, D.S. Fox, N.P. Bansal. Rare earth silicate environmental barrier coatings for $\mathrm{SiC} / \mathrm{SiC}$ composites and $\mathrm{Si}_{3} \mathrm{~N}_{4}$ ceramics, J. Eur. Ceram. Soc. 25 
(2005) 1705-1715.

(b) X.H. Zhong, H.Y. Zhao, X.M. Zhou, C.G. Liu, L. Wang, F. Shao, K. Yang, S.Y. Tao, C.X. Ding. Thermal shock behavior of toughened gadolinium zirconate/YSZ double-ceramic-layered thermal barrier coating, J. Alloy. Compd. 593 (2014) 50-55.

[34] A. Loganathan, A.S. Gandhi, Effect of phase transformations on the fracture toughness of t' yttria stabilized zirconia, Mater. Sci. Eng. A. 556 (2012) 927-935.

[35] X.R. Ren, W. Pan, Mechanical properties of high-temperature-degraded yttria-stabilized zirconia, Acta Mater. 69 (2014) 397-406.

[36] C. Bumgardner, B. Croom, X.D. Li, High-temperature delamination mechanisms of thermal barrier coatings: In-situ digital image correlation and finite element analyses, Acta Mater. 128 (2017) 54-63. 